\title{
DOMESTIC VIOLENCE AGAINST WOMEN IN NIGERIA: A PHILOSOPHICAL STUDY
}

\author{
Chris O. Abakare \\ ${ }^{1}$ Department of Philosophy, \\ Nnamdi Azikiwe University, \\ Ifite Road, 420110, Awka, Anambra State, Nigeria. \\ chrisabakare@gmail.com
}

\begin{abstract}
Family, apart from providing security and emotional support should provide the most secure environment for an individual to grow. However, domestic violence is largely evident in the Nigeria families and societies. Although, women are worshipped as deities at home in some cultures in Nigeria, they are also treated as second class members of the family. This is largely due to the patriarchal nature of the Nigerian society. The essence of this work is to investigate domestic violence against woman in Nigeria. This work discovers that the lack of physical power leads to general timidity in women. This work discovers that domestic violence is perpetrated by family members against women in the family, ranging from single assault to aggravated physical battery, threats, intimation, coercion, stalking, humiliating verbal use, forcible or unlawful entry, sexual violence, marital rape, dowry and even female genital mutilation. This work is of the opinion that domestic violence bluntly trips women of their most basic human rights, the right to safety in their homes and community and should be discourage.
\end{abstract}

Keywords: Domestic violence, Women, Patriarchy, Nigeria.

\section{INTRODUCTION}

Domestic violence is a widespread problem throughout the developed and developing world and makes serious impact on quality of human life and broader development (Melville \& McDowell 2018). Violence against women is the manifestation of a historically unequal power relationship between men and women. It is a conditioned response and is not natural or born of biological determinism. In the olden days, violence against women was as a result to the prevalent atmosphere of ignorance and feudalism (Matud 2018). Today violence against women is an uncontrollable phenomenon, which is a direct result of the rapid urbanization, industrialization and structural adjustment programmes which are changing the socio-economic scenario of our country.

In the Nigerian society, the problem of violence against women in the family is not new. In Nigeria, despite a women goddess been worshipped in the image of Orisha within the Yoruba cultural group, it is still disheartening to observe the brutal reality of women's existence (James 2018). Women in many Nigerian society have been the victims of humiliation, torture and exploitation from the time immemorial irrespective of the fact that they are also worshipped by different tribal groups (Umukoro \& Egbai 2016: Anweting \& Ogar 2018).

Also, family is supposed to be the first agency, which provides not only emotional and material support to its members but also serves as basic source of personal satisfaction, socialization and social control. However, due to patriarchal nature of the Nigerian family system, the family structure does not give equal importance to all members as role, power and status are strictly determined by age and gender. Women in Nigeria through the ages have been victimized, humiliated, tortured and exploited. There have been incidents of murder rape, abduction and torture from time immemorial. In spite of such a dark past, 


\section{Jumal Sosialisasi \\ Jurnal Hasil Pemikiran, Penelitian, dan Pengembangan \\ Keilmuan Sosiologi Pendidikan \\ Vol 8, Nomor 1, Maret 2021}

violence against women in Nigeria has only received little attention. Moreso, much attempt has not been made to find out the reason why such a socially relevant theme has been left neglected and ignored. This paper argues that in our current postindustrial era, with the advancement in technology which has brought significant structured and role changes in the family.

\section{DOMESTIC VIOLENCE}

Domestic violence represents a serious abuse of power within family, trust or dependency relationships. It undermines the basic rights of people who because of the gender, age, disability or dependence, are most vulnerable to abuse. It is further defined as a serious social and criminal problem that can result in the death or disablement of victims. It can involves killing or physical and sexual assault. It also involves other forms of abusive behaviour, such as emotional abuse, financial deprivation and exploitation and neglect. Domestic violence often remains a hidden problem which has long lasting effects on is victims. United Nation's framework for nodal legislation on domestic violence states that all acts of gender-based-violence physical, psychological and abuse by a family members against women in the family, ranging from single assault to aggravated physical battery, kidnapping, threats, intimation, coercion, stalking, humiliating verbal use, forcible or unlawful entry, arson, destruction of property, sexual violence, marital rape, dowry or related violence, female genital mutilation violence related to exploitation through prostitution, violence against household workers and attempts to commit such acts shall be termed domestic violence (Furlow 2018; Yta et al., 2020). The problem of domestic violence in Nigeria stems from a cultural bias against women (Ishola 2016). Women who challenge their husband's right to control their behaviour or who ask for household money or step out of the house without permission may face violence. This process leads men to believe their notion of masculinity and manhood, which is reflected to the degree by which they control their wives.

The definition of 'domestic violence' has included 'physical abuse' 'sexual abuse' and 'economic abuse'. It is important to clarify here the concept of 'violence' this has been described by Makwana (2009) has defined violence as "the overtly threatened or overtly accomplished application of force which result in the injury or destruction of persons or their reputation" (Kamal 2018: 64). Thus rape, kidnapping, murder, wife battering, sexual abuse, eve teasing are all examples of violence against women. Domestic violence is any act of physical, sexual or psychological abuse, or the threat of such abuse, inflicted against a women by a person intimately connected to her through marriage, family relation, or acquaintanceship. It is universal and has its root in the socio cultural set up of the society (Khan \& Ratele 2020). The frequent understanding of domestic violence against women is that it is limited to physical harm perpetrated on adult women within a marital relationship. While this conception may capture a large universe of the experience of women, it is predicated on the assumption that women primarily live in nuclear families. However, there are varieties of living arrangements ranging from joint families to nuclear families, to single parent families. Women may also be found in an established relationship or in the process of divorce or separation. Violence may not always be restricted to current husband but may extend to boyfriends, former husbands and other family members, such as parentsin-law and in-laws. A definition of Domestic Violence that covers these multiple dimensions would lead to interventions that are more inclusive of the experiences of the women. 
In the Nigerian Violence Against Persons (Prohibition) Act of 2015, domestic violence has been defined as, any act, omission or commission or conduct of the respondent shall constitute domestic violence in case it (Ngozi et al., 2018):

(a) Harms or injuries or endangers the health, safety, life, limb or well-being, whether mental or physical, of the aggrieved person or trend to do so and includes causing physical abuse, sexual abuse, verbal and emotional abuse and economic abuse; or

(b) Harasses, harms, injures or endangers the aggrieved person with a view to coerce her or any other person related to her to meet any unlawful demand for any dowry or other property or valuable security; or

(c) Has the effect of threatening the aggrieved person or any person related to her by any conduct mentioned in Clause (a) or Clause (b); or

(d) Otherwise injuries or causes harm, whether physical or mental, to the aggrieved person. Keeping in view the social and cultural aspect of Nigerian society, we can define domestic violence as all acts of gender-based physical, psychological and abuse by a family members against women in the family, ranging from single assault to aggravated physical battery, threats, intimidation, coercion, humiliating, verbal use, sexual violence, marital rape, dowry or related violence, violence against household workers and attempts to commit such acts shall be termed as domestic violence.

Domestic violence is a pervasive serious social malady and a major health problem. It has been in existence for a very long time. It bluntly, trips women of their most basic human rights, the right to safety in their homes and community, and carried to the extreme, it may kill, despite its cost in lives, health, economically wellbeing and work productivity and its impact on other social-economic variables, domestic violence tended and still tends to be a 'Crime of Silence' (Ngozi et al., 2018). This ensures that information's about domestic violence is sketchy and as a consequence, the perpetrators often escape accountability and continue to commit violent acts.

\section{DOMESTIC VIOLENCE GLOBAL SCENARIO}

"Violence at home" is a shocking connotation because "home" is supposed to be the safest place for anyone. Spine chilling is the fact that for many women and children, this home is a place where they face gore terror and violence. It is a shame on the human race that this violence at home is perpetrated by none else but their own close family members. Irrespective of a country's culture, class, religion, modernization, advancement and development, domestic violence against women and children is widely prevalent. Global dimensions of domestic violence are quite alarming. No society can claim to be free of such violence, there is variation only in the patterns and trends of the regions. Studies estimate that from country to country, 10 to 15 per cent of women have experienced physical violence by intimate partner or other close family member (Campo 2015). Because of inconsistency in defining domestic violence, it is difficult to get the actual violence rate.

Most common forms of domestic violence prevalent through-out the world are women and girls being battered, raped and even murdered. Violence also includes forced pregnancy, forced abortion; sterilization dowry related violence and killing in the name of honour. Even the older and widowed women are not spared from this abuse. Before now, when a woman's intimate partner sexually raped a woman, it was not a crime. But, legislation against martial rape have begun in some countries like USA, UK, Australia, Canada, New Zealand, Mexico etc. A UN digest quotes "domestic violence victim survivor's report that psychological violence is even more severe than compared to 


\section{Jumal Sosialisasi \\ Jurnal Hasil Pemikiran, Penelitian, dan Pengembangan \\ Keilmuan Sosiologi Pendidikan \\ Vol 8, Nomor 1, Maret 2021}

physical brutality" (McCann \& Pearlman: 117). The mental stress, which the victims undergo, leads to a high percentage of suicide and suicide attempts. Scholarly data reveals that even in most advanced and industrialized country like USA, as many as 30 to 40 per cent of battered women attempt suicide. Sri Lanka also rates the highest in suicide attempts (Indu et al., 2017).

In countries like Bangladesh, Kenya, Canada, Thailand and USA, murder by the batterers is highly prevalent (Skovlund et al., 2018). Russia and India also rates high in women being killed by their intimate partners (Skovlund et al., 2018). Furthermore, a most invisible and sinful abuse, in most countries, is the incest or sexual abuse against children and adolescents. It is invisible because the crime is perpetrated often by a child's father, step father, brother, uncle or any other male relative in position of trust. The right of the child is usually sacrificed in order to protect the name of the family. And the children out of shame and fear hesitate to report the matter. Several studies have reported that children exposed to domestic violence exhibit more aggressive and anti-social behaviour. In Asia, in countries like India and Pakistan more values is placed for "sons" and hence extreme steps of discrimination against female children is highly prevalent. Also, the children of destitute families from poor African countries are usually sent to Middle East and Europe for jobs and ultimately end up as prostitutes. Traffickers buy the labour of young girls and women to earn easy money. In Ghana, a ridiculous practice of donating the wives for protection of family is being followed (). A similar practice exists in South India, where young women and girls are donated to serve temple (devdasis) and they often end up as prostitutes. Moreover, around the world, under the garb of cultural, religious and social practices, many women and girls suffer very harmful and life-threatening violence (Vawda 2018).

Female Genital Mutilation (FGM) is one such drastic violence. It is mostly prevalent in Africa, some regions of Asia, Middle East and in certain immigrant communities of North America, Europe and Australia. It can lead to long term psychological trauma, extreme physical suffering, and infertility and ultimate death (Mandara 2004). Conclusively, this world wide suffering of women and children in their own "Homes" will not be eased until families, NGOs, social institutions and government at large address the issue directly. Women and children have right to protection even in their homes. Domestic violence needs to be recognized as a "crime" by the law enforcement authority and judicial system and the perpetrator must be punished.

\section{SUGGESTIONS ON CUBING DOMESTIC VIOLENCE ON WOMEN IN NIGERIA}

The government and voluntary organizations are making efforts towards ending or minimizing violence against women. The efforts of the government are in the shape of enacting relevant legislations, issuing orders and launching various women welfare schemes. But their implementation remains tardy, at the lower level government functionaries are not gender sensitive. Laws pertaining to protection of women rights and prevention of domestic violence should be made more strict and enforced without any loopholes. The voluntary organizations are taking both preventive as well as reactionary measures. But efforts of the voluntary organizations suffer from paucity of funds and infrastructure.

Education of the girl child is the first step towards a better society with fewer incidents of violence. Campaigns aimed at men and women to increase awareness and change attitudes about gender inequality are also effective tools. As individuals and responsible citizens, we need to spread awareness and report any act of violence against 
women around us. It was said that woman is an enemy of woman. So to minimize the domestic violence, woman should consider that According to the expert's opinion alcoholism plays a crucial role in perpetrating violence against women as it has an influence on almost all other attributes. Therefore efforts must be taken to address alcoholism. In many cases those who involve in violence against women are under the influence of alcohol, sale of liquor should be banned within or around the residential areas.

\section{CONCLUSION}

Domestic violence represents a serious abuse of power within family, trust or dependency relationships. It undermines the basic rights of people who because of the gender, age, disability or dependence, are most vulnerable to abuse. It is further defined as a serious social and criminal problem that can result in the death or disablement of victims. It can involves killing or physical and sexual assault. It also involves other forms of abusive behaviour, such as emotional abuse, financial deprivation and exploitation and neglect. Domestic violence often remains a hidden problem which has long lasting effects on is victims. United Nation's framework for nodal legislation on domestic violence states that all acts of gender-based-violence physical, psychological and abuse by a family members against women in the family, ranging from single assault to aggravated physical battery, kidnapping, threats, intimation, coercion, stalking, humiliating verbal use, forcible or unlawful entry, arson, destruction of property, sexual violence, marital rape, dowry or related violence, female genital mutilation violence related to exploitation through prostitution, violence against household workers and attempts to commit such acts shall be termed domestic violence.

The problem of domestic violence in Nigeria stems from a cultural bias against women. Women who challenge their husband's right to control their behaviour or who ask for household money or step out of the house without permission may face violence. This process leads men to believe their notion of masculinity and manhood, which is reflected to the degree by which they control their wives. Domestic violence is a problem that affects the lives of many women both in the urban and the rural areas. It is also an episode that has been found to recur throughout the life cycle of women and has extensive repercussions. Violence against women takes many forms-physical, sexual, psychological and economic. These forms of violence are interrelated and affect women even from before birth till old age. Women who experience violence suffer a range of health problems and their ability to participate in public life is diminished. Violence against women harms families and communities across generations and reinforces other violence prevalent in society. Violence against women also impoverishes women, their families, communities and nations. Violence against women is not confined to a specific culture, region or country, or to a particular group of women within a society. The roots of violence against women lie in persistent discrimination against women.

Within the last few decades, gradual improvements in women's status due to women's activism in various parts of the world has helped slowly to increase the visibility of domestic violence as a social problem. Despite this, violence against women within the family home, until very recently, has received little attention as either a social or a public health issue. The sensitivities and stigma associated with domestic violence, the perception 
that it is primarily a judicial and legal issue, and the lack of data on the dimensions of abuse, have hampered understanding and the development of appropriate interventions.

\section{REFERENCES}

Anweting, K. I., \& Ogar, O. A. (2018). Political Violence in Nigeria and Its Implication for National Development. GNOSI: An Interdisciplinary Journal of Human Theory and Praxis, 1(1), 84-92.

Campo, M. (2015). Domestic and family violence in pregnancy and early parenthood: Overview and emerging interventions. In Australian Institute of Family Studies. https://aifs.gov.au/cfca/sites/default/files/publication-documents/cfca-resource-dvpregnancy.pdf

Coomaraswamy, R. (1994). Rapporteur on violence against women appointed. In WIN News (Vol. 20, Issue 3).

Ezejiofor, A. (2011). Patriarchy, Marriage and the Rights of Widows in Nigeria. UJAH: Unizik Journal of Arts and Humanities, 12(1). https://doi.org/10.4314/ujah.v12i1.9

Gibson, S. (1993). On sex, horror and human rights. Women, 4(3), 250-260. https://doi.org/10.1080/09574049308578167

IAU General Assembly. (2006). IAU 2006 General Assembly: Resolutions 5 and 6. System, 5-6.

Ibok, A. K., \& Ogar, O. T. (2018). Traditional Roles of African Women in Peace Making and Peace Building: An Evaluation. GNOSI: An Interdisciplinary Journal of Human Theory and Praxis, 1(1), 41-58.

Indu, P. S., Anilkumar, T. V., Pisharody, R., Russell, P. S. S., Raju, D., Sarma, P. S., Remadevi, S., Amma, K. R. L., Sheelamoni, A., \& Andrade, C. (2017). Prevalence of depression and past suicide attempt in primary care. Asian Journal of Psychiatry, 27, 48-52. https://doi.org/10.1016/j.ajp.2017.02.008

Ishola, S. A. (2016). Domestic Violence: The Nigerian Experience. Asia-Africa Journal of Mission and Ministry, 13, 3-16. https://doi.org/10.21806/aamm.2016.13.01

Kamal, I. (2018). Gender Inequality and Violence against Women. Open Access Journal of Biomedical Engineering and Biosciences, 2(4). https://doi.org/10.32474/oajbeb.2018.02.000142

Khan, A. R., \& Ratele, K. (2020). Assessing the Policy Implementation of the Bangladeshi Domestic Violence Act: Any Lessons for Protecting South African Women in their Homes? South Review of Sociology. https://doi.org/10.1080/21528586.2020.1741443

Mandara, M. U. (2004). Female genital mutilation in Nigeria. International Journal of Gynecology and Obstetrics, 84(3), 291-298. https://doi.org/10.1016/j.ijgo.2003.06.001

Mberu, B. U. (2007). Household structure and living conditions in Nigeria. In Journal of Marriage and Family (Vol. 69, Issue 2, pp. 513-527). https://doi.org/10.1111/j.1741$\underline{3737.2007 .00380 . x}$

McCann, I. L., \& Pearlman, L. A. (2015). Psychological trauma and adult survivor theory: Therapy and transformation. In Psychological Trauma and Adult Survivor Theory: Therapy and Transformation. https://doi.org/10.4324/9781315803715

Milazzo, A., \& Walle, D. van de. (2019). Nutrition, Religion and Widowhood in Nigeria. Economic Development and Cultural Change. https://doi.org/10.1086/704159 
Jumal Sosiafisasi

Jurnal Hasil Pemikiran, Penelitian, dan Pengembangan

Keilmuan Sosiologi Pendidican

Vol 8, Nomor 1, Maret 2021

Ngozi, C., Iyioha, I., \& Durojaye, E. T. (2018). The Violence Against Persons Prohibition Act, the Maputo Protocol and the Rights of Women in Nigeria. Statute Law Review, 39(3), 337-347. https://doi.org/10.1093/slr/hmx009

Nigam, S. (2019). Legislating the laws relating to domestic violence. In Women and Domestic Violence Law in India (pp. 48-89). https://doi.org/10.4324/9780429343575$\underline{3}$

Omideyi, A. K. (1983). Age at marriage and marital fertility in Eastern Nigeria. Genus, 39(1-4), 141-154.

Orji, E. O., Kuti, O., \& Fasubaa, O. B. (2002). Impact of infertility on marital life in Nigeria. International Journal of Gynecology and Obstetrics, 79(1), 61-62. https://doi.org/10.1016/S0020-7292(02)00180-7

Peter, E., \& Chinyere, A. (2015). Gender inequality in reproductive health services and sustainable development in Nigeria: A theoretical analysis. International Journal of Sociology and Anthropology, 7(2), 46-53. https://doi.org/10.5897/ijsa2014.0577

Skovlund, C. W., Mørch, L. S., Kessing, L. V., Lange, T., \& Lidegaard, J. (2018). Association of hormonal contraception with suicide attempts and suicides. American Journal of Psychiatry, 175(4), 336-342. https://doi.org/10.1176/appi.ajp.2017.17060616

Smith, D. J. (2016). Modern Marriage, Masculinity, and Intimate Partner Violence in Nigeria. In Marital Rape (pp. 41-54). https://doi.org/10.1093/acprof:oso/9780190238360.003.0004

United Nations. (2007). Women, gender equality and sport. Women2000 and beyond, December, $1-40$.

Vawda, N. B. M. (2018). Suicide attempts during pregnancy in South Africa. In South African Journal of Psychiatry (Vol. 24, Issue 1). https://doi.org/10.4102/sajpsychiatry.v24i0.1154

Umukoro, G. M., \& Egbai, M. J. (2016). Gender Mainstreaming, A Panacea For Quality Service And Good Governance: An Insight Into The Political Systems In Francophone Africa. Global Journal of Applied, Management and Social Sciences, 11 .

Yta, E. M., Umukoro, G. M., \& Ekpe, M. E. (2020). Increasing Community discourse and Action on GBV prevention in Akai Effa and Idundu, Cross River State. PINISI Discretion Review, 4(1), 123-134. 